\title{
Assessment of building energy-saving policies and programs in China during the 11th Five-Year Plan
}

\author{
Nan Zhou • Michael Mcneil • Mark Levine
}

Received: 21 September 2010 / Accepted: 7 January 2011 /Published online: 20 March 2011

(C) The Author(s) 2011. This article is published with open access at Springerlink.com

\begin{abstract}
China's 11th Five-Year Plan (FYP) sets an ambitious target to reduce the energy intensity per unit of gross domestic product by $20 \%$ from 2005 to 2010 (NDRC 2006). In the building sector, the primary energy-saving target allocated during the 11 FYP period is 100 Mtce. Savings are expected to be achieved through the strengthening of enforcement of building energy efficiency codes, existing building retrofits and heat supply system reform, followed by energy management of government office buildings and large-scale public buildings, adoption of renewable energy sources. To date, China has reported that it achieved the half of the $20 \%$ intensity reduction target by the end of 2008 ; however, little has been made clear on the status and the impact of the building programs. There has also been lack of description on methodology for calculating the savings and baseline definition, and no total savings that have been officially reported to date. This paper intends to provide both quantitative and qualitative assessment of the key policies and programs in building sector that China has instituted in its quest to fulfill the national goal. Overall, this paper concludes that the largest improvement for building energy efficiency were achieved in new buildings; the program to improve the energy management in government and large scale public buildings are in line with the target; however, the progress in the area of existing building retrofits,
\end{abstract}

N. Zhou $(\bowtie) \cdot$ M. Mcneil $\cdot$ M. Levine

Ernest Orlando Lawrence Berkeley National Laboratory, One Cyclotron Rd, MS 90R4000,

Berkeley, CA 94720-8136, USA

e-mail: NZhou@lbl.gov particularly heating supply system reform lags behind the stated goal by a large amount.

Keywords China · Building · Energy efficiency policy $\cdot$ Evaluation $\cdot 11^{\text {th }}$ Five Year Plan $\cdot$ Energy saving $\cdot$ Building codes $\cdot$ Exist building retrofit $\cdot$ Heat supply system reform $\cdot$ Enforcement

\section{Introduction}

Overview

Building energy consumption accounts for $25 \%$ of the total primary energy use in China (Zhou et al. 2007). ${ }^{1}$ Total floor area was approximately 58 billion $\mathrm{m}^{2}$ in 2007 (NBS 2008). ${ }^{2}$ Two billion $\mathrm{m}^{2}$ of building space have been added each year during the past several years (TUBERC 2009). This is thought to represent half of the construction in the entire world (Xinhua 2007).

\footnotetext{
${ }^{1}$ The building energy consumption data has been adjusted based on the calibration performed to support the Lawrence Berkeley National Laboratory (LBNL) China bottom-up end use model. This estimate reflects the energy by end use (e.g., space heating), information not available from official data reported in China's Statistical Yearbooks. For details, refer to Zhou and Lin (2008).

${ }^{2}$ Urban building floor area is obtained from the 2008 China Statistical Yearbook. Statistical information is not available for rural building floor area. We estimate the floor area using per capita floor space of houses from Table 9-37, Housing Conditions of Rural Household by Region (2007), and rural population from Table 3-4, Population by Urban and Rural residence and Region in 2008 China Statistical Yearbook (2007).
} 
China has a centralized Ministry of Housing and Urban-Rural Development (MOHURD) under the State Council (see Fig. 1) which is responsible for regulating a building industry that ${ }^{3}$ is by any measure by far the largest in the world. A network of Construction Commissions in the major cities works under local government administration and is supervised by the provincial Construction Department. Similar to the Construction Commissions, these provincial Construction Departments work under the provincial government and are supervised by MOHURD. Provincial and city level authorities in the building sector (Construction Commissions and Provincial Construction Department) oversee building construction, including the granting of building permits and the enforcement of building codes, as well as a parallel network of building research institutes to provide technical expertise and support to MOHURD and the building industry. Within MOHURD, building energy standards fall under the jurisdiction of the Department of Standards and Norms. The technical development of building energy standards is the responsibility of the Department of Science and Technology, in collaboration with building research institutes, universities, and industry representatives. For example, for the current residential and public building standards, Code Compilation Committees were organized under the leadership of the China Academy of Building Research in the Department of Science and Technology. For the 11th Five-Year Plan, the Department of Science and Technology (DST) is responsible for energy efficiency retrofits of existing buildings, monitoring, and energy management in government and large-scale public buildings, as well as renewable energy application, whereas the Department of Urban Development is in charge of carrying out the heat supply system reform task. Building code enforcement falls under the Department of Quality and Safety's jurisdiction, and the DST is also supporting the task by assembling expert team and conducting random checking (Fig. 1).

\footnotetext{
${ }^{3}$ In 2008, under the institutional reform framework, China's Ministry of Construction (MOC) was transformed into the MOHURD. Significant adjustments in the responsibilities of the new ministry include establishing the authority of MOHURD to resolve housing problems for low income families, to address, housing security, and to promote sustainable urban development.
}

To realize the energy-saving goal stated in the 11th FYP and implement the various policies and measures, leading groups of key officials were established at the responsible government agencies at all levels (provincial, city, district, and national levels). In 12 provinces (city, district), an energy-saving coordination leading group that involves the Departments of Finance, Construction, and the Development and Reform Commissions has further been established. Corresponding agencies have also been set up at each city. In Shanxi province, energy conservation supervision agencies have been established at both provincial and city levels with a total of 111 staff members. In Shanghai, 19 districts have set up energy conservation management offices, with a total staff of 101.

A summary of policies and regulation measures adopted to promote and/or require energy efficiency in buildings during the 11th Five-Year Plan is shown in Table 1.

Stated policy and program goals

In 2006, the State Council required MOHURD's predecessor, the Ministry of Construction (MOC), to draft a bill to strengthen energy efficiency in buildings. This Building Energy Conservation Regulation Ordinance Bill was expected to come into effect in the beginning of 2007, but was delayed to October 2008 and renamed to Civil Building Energy Conservation Ordinance (MOC/MOHURD 2008). The bill includes regulations in six areas: building energy management systems, energy efficiency rating systems, energy consumption statistics, energy-saving retrofits, construction practices, and licensing of new buildings (Wu 2009). For new buildings, the law requires full implementation of the standard and tightens it in some regions to $65 \%$ reduction compared to buildings without insulation. For existing buildings, it requires government buildings (and large commercial buildings) to take the lead in energy retrofits. It also promotes the use of renewable energy by encouraging local jurisdictions to support such applications.

In addition to the standards and encouragement of energy retrofits, the bill requires MOHURD to propose a method for energy efficiency labeling of buildings (to be mandatory for residential and most commercial buildings); to establish a uniform system for collecting and analyzing energy consumption data; to establish three levels of products and practices in buildings categories- 


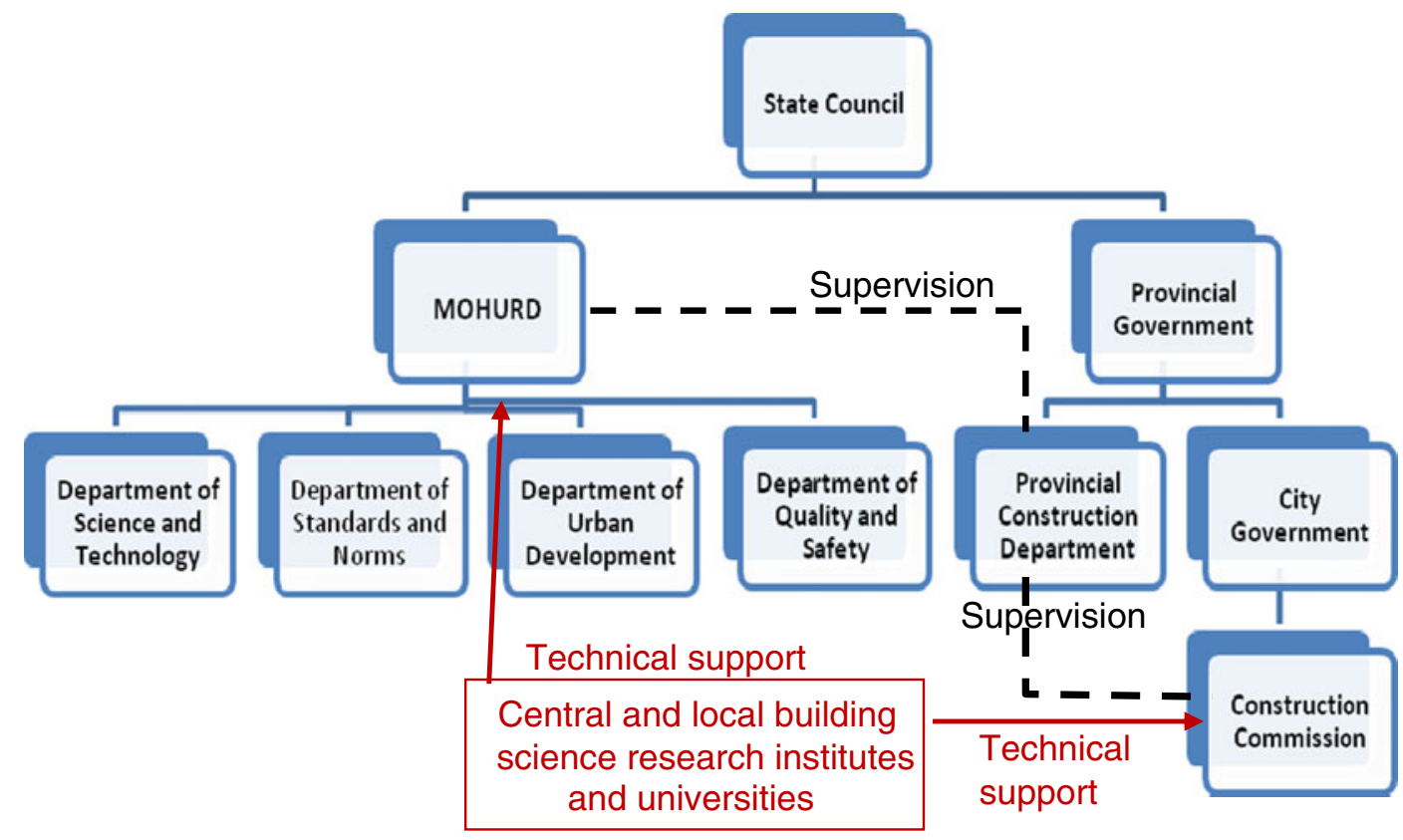

Fig. 1 Government organization chart in building energy efficiency

desired, restricted, or prohibited-based on energy consumption; and to encourage local governments to provide incentives for energy efficiency measures in new and existing buildings. These efforts remain exploratory, but are expected to have increasing impacts over the coming years.

Under the framework of the 11th FYP's 20\% energy intensity reduction target, the energy-saving target for the building sector is 100 Mtce in primary energy units (Wu 2009). A savings of 62 Mtce will be achieved through the strengthening of enforcement of the building energy efficiency codes, 16 Mtce will be from existing building retrofits and heat supply system reform, followed by 11 Mtce from energy management of government office buildings and large-scale public buildings, and 11 Mtce from adoption of renewable energy sources. In addition, there is a goal of saving 29 TWh through the Green Lights program.

\section{Building energy efficiency codes}

\section{Quantitative evaluation}

China adopted building energy standards in stages, starting with an energy design standard for residential buildings in the heating zone of north China in 1986.
This was followed by a standard for tourist hotels in 1993, for residential buildings in the hot-summer coldwinter region of central China in 2001, and for hotsummer warm-winter region of south China in 2003. A national energy efficiency design standard for public buildings (the term used in China to refer to commercial buildings) was adopted and implemented in 2005 . Lastly, a revised national energy design standard for residential buildings that combines the three previous regional standards has been under development since 2005 and was expected to be completed in early 2007 , but has been delayed without announcement of an expected date of implementation.

Earlier standards for residential buildings set targets to reduce building energy consumption compared to pre-existing construction by $30 \%$ in 1986 and by $50 \%$ in 1995 . The 2005 standard for public buildings set the target at 50\% energy reduction compared to pre-buildings built in the $1980 \mathrm{~s}$ in China. Of the $50 \%$ saving target, $13-25 \%$ is expected to be achieved from improvements to the building envelope, 16-20\% from improvements in the heating, ventilation, and air conditioning system, and $7-18 \%$ from lighting efficiency improvements (Feng et al. 2009). In addition to national or regional standards, there have been local standards in major cities, such as Beijing, Shanghai, Wuhan, and Chongqing. 


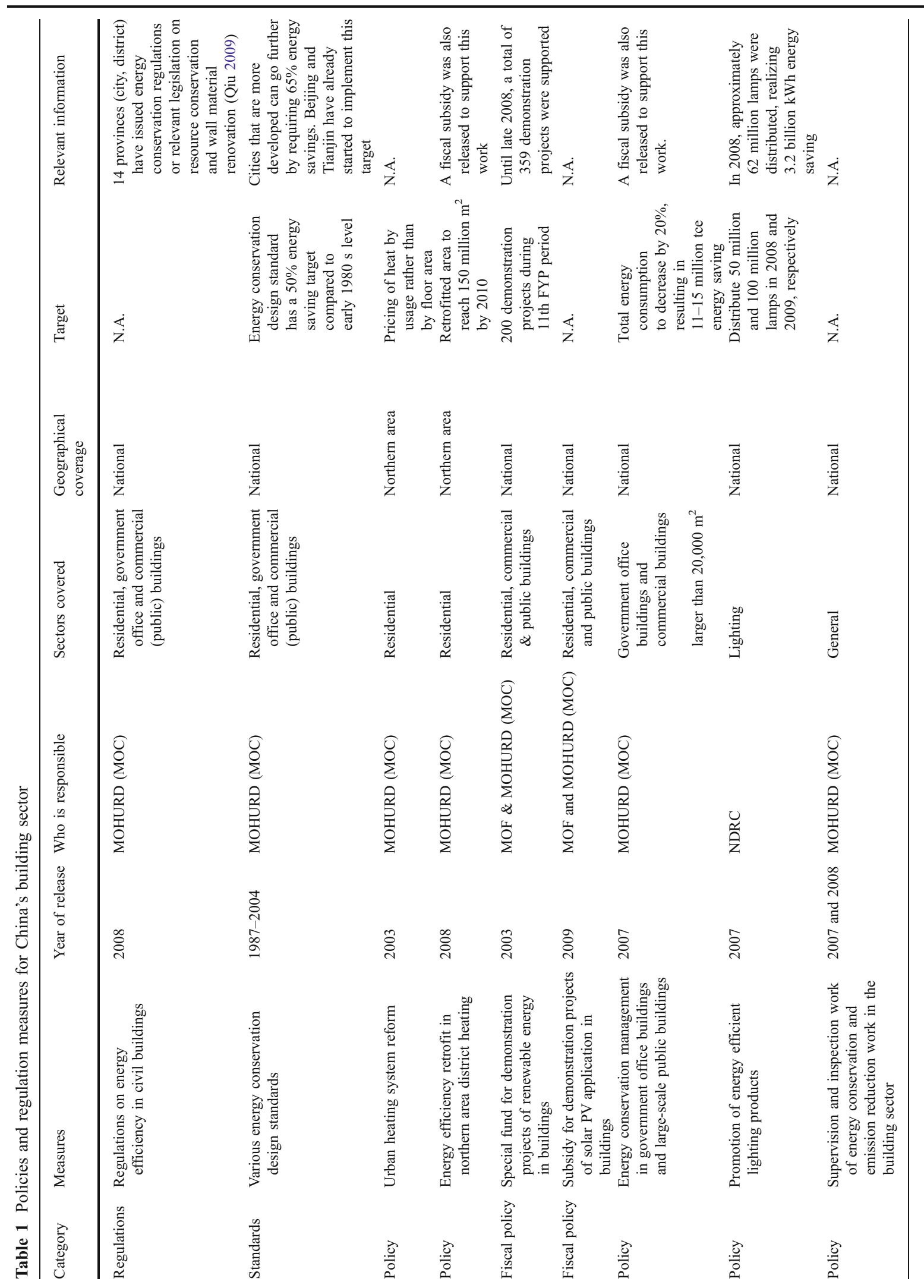


Although the building standards cover all new construction in China; in 2006, just $60 \%$ of new buildings in large urban areas met the energy-saving standard during the design stage and only $23 \%$ at the construction stage, according to a survey conducted by MOHURD. In southern China, the percentages were just $10 \%$ and $8 \%$, respectively (Wu 2009). However, since the announcement of the 11th FYP, MOHURD has strengthened the enforcement effort and a systemic enforcement and monitoring approach has been put in place to improve the compliance rate. Inspection and random checking have been implemented at all levels of the government from the county-city level to the central government. Based on these efforts, more recent survey results show very much higher implementation rates: in $2008,98 \%$ at the design phase and $81 \%$ at construction phase (Table 2; Qiu 2009).

Savings from building codes arise from two separate policy initiatives. The first of these is the establishment of codes for new residential and commercial buildings that mandate a $50 \%$ reduction in heating energy consumption relative to the existing stock. The second is an initiative beginning in 2006 to significantly improve the level of enforcement of these codes in order to raise compliance rates in both building design and construction phases.

Regarding enforcement, Table 2 provides information on historical and projected compliance rates for the design and construction phases, indicating that compliance was reported to be high for both phases by 2008 (Qui and Wu 2009). These high compliance rates are for construction in urban areas. Building energy codes do not apply in rural areas, which constitute a substantial fraction of overall construction.

In order to estimate savings from the building energy efficiency codes initiatives, two counterfactual baselines were established. The first, labeled the "No Building Codes" scenario, assumes the absence of building codes and thus no reductions in new building heating and cooling intensity. In the second "Moderate Enforcement Scenario", building codes exist and the building code construction phase compliance rate trend from 2001 to 2005 is assumed to continue without acceleration. These enforcement rates are assumed to hold for both urban residential and commercial buildings. No enforcement of codes is assumed for rural buildings; therefore, energy consumption for rural buildings is assumed to be the same in all scenarios.

The "No Building Codes" scenario energy consumption for buildings is based on Lawrence Berkeley National Laboratory (LBNL) estimates of building floor space and end-use intensities (Zhou et al. 2007), modified to represent constant level of heating and cooling loads at 2,000 levels, at which time the building stock was largely unaffected by building codes. For the actual building code enforcement and the "Moderate Enforcement" scenarios, reduction in new building heating and cooling energy were combined with LBNL construction estimates and enforcement rates in Table 2 to derive total energy consumption for buildings. No reduction in heating load is assumed for buildings using district heat. In the absence of increased occupant control of heating within buildings, we assume the same amount of heat will be supplied to the building independent of shell measures. Therefore, while building codes may result in a higher degree of occupant comfort in such buildings, energy consumption will be unaltered.

Finally, we produce a scenario in which savings result from both establishment and enforcement of building codes. The difference between the "Moderate Enforcement" case and the "No Building Codes" case yields the savings due to moderate code implementation. Savings from new enforcement are given by the difference between the "Actual Enforcement" case and the "Moderate Enforcement" case. Table 3

Table 2 Compliance rate of energy efficiency standards in urban areas

\begin{tabular}{llllllllll}
\hline \multicolumn{7}{c}{ Rate of compliance with building energy efficiency codes } \\
\cline { 2 - 8 } & $2001(\%)$ & $2004(\%)$ & $2005(\%)$ & $2006(\%)$ & $2007(\%)$ & $2008(\%)$ & 2009 (projected; \%) & 2010 (projected; \%) \\
\hline Design phase & 5 & 54 & 59 & 96 & 97 & 98 & 100 & 100 \\
Construction phase & 2 & 20 & 23 & 54 & 71 & 81 & 92 & 100 \\
\hline
\end{tabular}

Source:2001-2008 (Qiu 2009, Wu 2009); 2009-2010 projections based on LBNL assumptions 
Table 3 Primary energy savings due to establishment and enforcement of building codes

200620072008 Projected 2009 Projected 2010 Cumulative 2006-2008

Primary energy savings (Mtce)

\begin{tabular}{|c|c|c|c|c|c|c|c|}
\hline \multirow[t]{3}{*}{ Establishment of building codes } & Residential & 1.9 & 2.6 & 3.5 & 4.5 & 5.7 & 8.0 \\
\hline & Commercial & 3.7 & 5.2 & 6.9 & 8.8 & 11.1 & 15.7 \\
\hline & All Buildings & 5.6 & 7.8 & 10.4 & 13.3 & 16.8 & 23.8 \\
\hline \multirow[t]{3}{*}{ Building codes enforcement } & Residential & 0.5 & 1.3 & 2.3 & 3.4 & 4.8 & 4.0 \\
\hline & Commercial & 1.1 & 2.8 & 4.8 & 7.1 & 9.7 & 8.6 \\
\hline & All Buildings & 1.6 & 4.0 & 7.0 & 10.5 & 14.4 & 12.6 \\
\hline \multirow[t]{3}{*}{ Total } & Residential & 2.4 & 3.9 & 5.8 & 7.9 & 10.5 & 12.1 \\
\hline & Commercial & 4.8 & 7.9 & 11.7 & 15.9 & 20.8 & 24.3 \\
\hline & All Buildings & 7.2 & 11.8 & 17.4 & 23.8 & 31.2 & 36.4 \\
\hline
\end{tabular}

provides these savings in terms of primary energy. ${ }^{4}$ In this table, savings from the "Establishment of Building Codes" is the difference between the "Moderate Enforcement" scenario and the counterfactual of no building codes. Savings from "Building Codes Enforcement" is the difference between the 20012005 compliance rate trend and the actual and projected compliance rate in 2006-2010.

The analysis shows that if no improvements from codes had been made to new buildings relative to the stock, heating and cooling primary energy would have been 17 Mtce higher than it actually was in 2008. If the current trends continue, leading to total enforcement of $100 \%$ by 2010 , heating and cooling primary energy will be 31 Mtce lower in that year relative to the No Building Codes case. Cumulative savings from building codes between 2006 and 2008 total 36 Mtce, and could reach 91 Mtce by 2010 according to current trends. Assuming that prevailing enforcement trends would have continued in the absence of additional actions taken, the initiative to significantly increase enforcement roughly doubled the energy savings of building codes as a whole. The newly reported data shows energy saved by new energy-saving buildings built in January-October 2007 equals to 5 Mtce (Qiu 2009), and the figure increased to 9 Mtce of energy saving in 2008 (Qiu 2009), which validates our estimates.

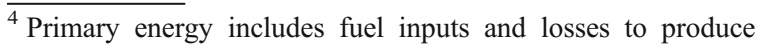
electricity. The ratio between final electricity and primary input energy is taken from the LBNL China bottom-up end use model, which models the Chinese electricity generation fuel mix, plant efficiency and transmission and distribution losses.
}

Qualitative evaluation

The main goal for new buildings in the 11th FYP is the full enforcement of the building energy codes, which calls for a $50 \%$ intensity reduction from building prior to codes. Based on economic affordability and other conditions, some regions are encouraged to increase the energy-saving target to $65 \%$. As a result, more stringent energy-saving targets (up to $65 \%$ ) have been implemented in Beijing and Tianjin, and will soon be followed by Shanghai and Chongqing. Other areas such as Inner Mongolia, Shandong, Henan, and Hebei Provinces have also partially implemented more stringent local energy saving standards. During the 12th Five-Year Plan period, all new buildings are expected to meet the $65 \%$ saving target (Hao 2009).

Supervision and enforcement for energy efficiency in new buildings is conducted through regular and random inspections. Regular inspection for new construction follows a "loop system". This is done under the existing market entry control system through a series of administrative licenses. New construction projects have to first apply for land use permit from local planning authority. In this phase, the Planning Bureau works together with the Construction Commission to inspect whether the main facade, lay-out, and shape of the design meet the energy efficiency requirements. The local construction department will then evaluate and approve the blueprint and engineering plans. Once the construction blueprints have been evaluated to ensure compliance with mandatory energy standards, the local construction department will issue the construction 
permit. If the proposed construction plan or blueprints fail to receive approval, permits will not be issued and construction cannot begin. Once construction on the new building begins, the building design and construction enterprises and respective supervisory units are responsible for obtaining energy labeling certification, verification of construction completion and insulation quality assurance. In the construction phase, inspection is carried out to assure compliance with the energy conservation standard before the construction license is issued. Another inspection to confirm compliance with energy efficiency standards is conducted at the final acceptance phase of the project. Finished projects failing to comply with the standards at this stage are not accepted by the Construction Commission and thus are considered to be illegal construction. Because developers pay fees that support the compliance agencies, there is reason for concern about the integrity of the process. However, our discussions with officials indicate that there are strong incentives for compliance, as neither the accredited verifying institute nor the construction contractor or developer would risk their licenses to cheat. ${ }^{5}$ An illustration of this process is shown in Fig. 2.

Random inspections related to energy conservation and emission reduction have been conducted twice since 2008 (for 2007 and 2008 projects). The inspections are carried out by an evaluation team organized by MOHURD. The evaluation teams are sent to 20 provinces. Each team each consists of 10 20 experts and is in charge of evaluating three provinces. The team evaluates energy conservation work of the provincial Construction Commissions. They then evaluate three cites at three different levels: provincial capital, one random prefecture-level city, and one random county-level city. After the local evaluation, random checks on projects are then conducted. Projects that failed the random inspection are penalized through high fines, decreased certification level, and/or cancelation of their certification.

The inspection process is done through investigation of the submitted documents and construction drawings, and is checked with computer simulation results. Some adjustments are made based on weather data. After the building has been built, annual

\footnotetext{
${ }^{5}$ This is validated through the personal communications with various construction companies.
}

monitoring and checking of the energy consumption by fuel is conducted for all government buildings and large office buildings. Measurement of building performance such as the heat conduction value ( $U$ value) of the wall is conducted a year after the operation. For residential buildings, spot inspection is also carried out for selected residential districts each year. The costs of the inspection or energy audit are borne by the central and local government through their energy-saving funds (Wu 2009). For other public buildings and residential buildings, public notices have also been used. At the construction site, the energy performance of a building including energy efficiency and renewable energy measures adopted are written on a banner that informs the public; this information is also written in the building/house purchase contract, the certificate of quality guaranty, as well as the occupant's Instructions. These documents are legally binding.

The majority of the inspections are carried out by the local government. The expert team at the central level mostly reviews paper documents. There are three to five institutes in each province that are accredited to conduct inspections ( Wu 2009) with the exception that Beijing and Shanghai each have about 10 institutes. On average, there are 20-30 people working in each institute, which makes the total number of inspectors in each city approximately 60 150 (Hao 2009). However, the institutes, such as local building science research institutes, generally are responsible for many tasks, with inspection being only one of them. This suggests that staffing may not be adequate to perform the inspections adequately. Nonetheless, the compliance rate after these measures were taken has increased dramatically, as noted in Table 2 for urban areas. The compliance rate is considered to be accurate at the prefecture level cities, whereas the compliance rate remains ambiguous for the small county level cities.

\section{Existing building retrofit and heat metering reform}

Quantitative evaluation

MOHURD and MOF jointly released the Opinion on Implementation of Heating System Measurement and Energy Conservation Retrofit for Existing Residential 
Fig. 2 Illustration of loop inspection system of energy conservation standard compliance

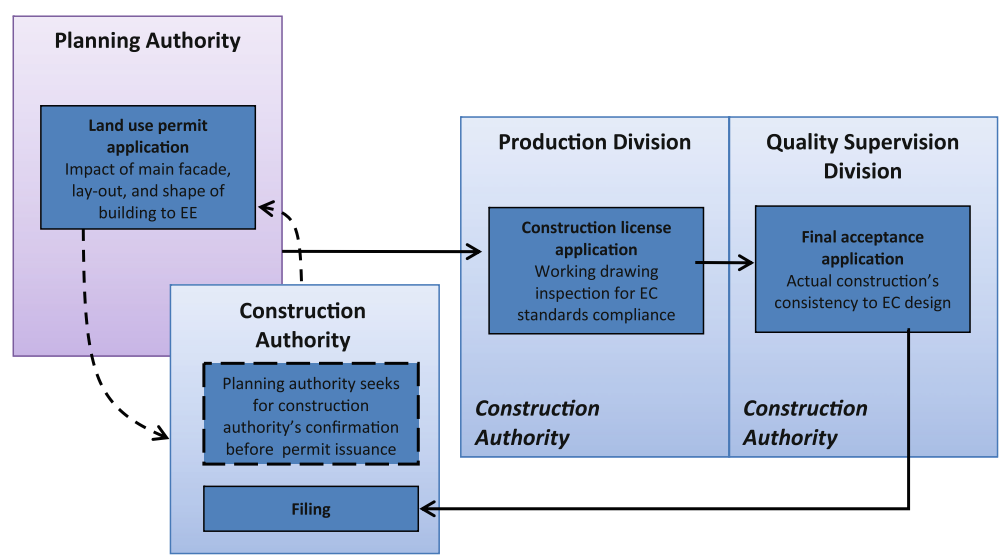

Buildings in Northern Heating Areas targeted at the retrofit of 150 million $\mathrm{m}^{2}$ floor area.

The goal is to realize $50 \%$ of heating intensity reduction after the retrofit compared with buildings built in the $1980 \mathrm{~s}$, and an additional 20\% reduction through the heating supply measurement reform by the end of 2010. Since the average heating intensity of the existing buildings used in this estimate is $25 \mathrm{kgce} / \mathrm{m}^{2}$, this implies savings of $12.5 \mathrm{kgce} / \mathrm{m}^{2}$ after the retrofits (Wu 2009) ${ }^{6}$ as well as savings of $5 \mathrm{kgce} / \mathrm{m}^{2}$ after the heating supply reform. This target can be further broken down to an estimated saving of 2 Mtce from retrofits for the 150 million $\mathrm{m}^{2}$ and another 14 Mtce from the heat supply reform including the heat pricing reform for the 2.7 billion $\mathrm{m}^{2}$ of urban buildings that have district heating system ( $\mathrm{Wu} 2009)$. The target was further disaggregated and assigned to provincial governments (Zhao 2009).

The retrofit consists of installation of heat metering and temperature control equipment, retrofitting the heat supply network for heat balance, and energy efficiency retrofit of building envelopes (Zhao 2009). The specific measures for the heat metering and temperature control retrofit includes installation of heat metering devices in boiler rooms and heat stations; meter installation in the heat entrance of the building or building group if the buildings have very similar characteristics; and development of a methodology to disaggregate the heat use. Measures for the heat supply network reform include

\footnotetext{
${ }^{6}$ The intensities vary by region; for instance, the average heating energy intensity in Beijing is $22.45 \mathrm{kgce} / \mathrm{m}^{2}$ after the retrofit, the intensity is supposed to be reduced to half at $11.27 \mathrm{kgce} / \mathrm{m}^{2}$.
}

energy efficiency improvement in the heat supply source and heat station (boilers, etc.); replacement of the network and installation hydraulic balance valves as needed; and installation of thermostat valves and regulating valves with automatic temperature control function together with pipe system replacement to improve the indoor heating system. Building envelope retrofits mostly targeted exterior windows, walls, and roofs with measures such as double-glazed windows, window frame sealing, more efficient windows, external insulation of the walls, and direct inverted roof insulation.

In 2008, about 39.5 million $\mathrm{m}^{2}$ of building area was retrofit, realizing primary energy savings of 270,000 tce energy saving (Qiu 2009). In 2009, the plans are to retrofit 53.5 million $\mathrm{m}^{2}$ heating area, bringing the total retrofitted area to 93 million $\mathrm{m}^{2}$. The project has been implemented only from 2008, so the sum of the areas retrofitted from 2008 to 2010 represents the cumulative total for the entire 11th Five-Year Plan.

By the end of 2009, the total retrofitted area will be the $62 \%$ of the total target, leaving another 60 million $\mathrm{m}^{2}$ to be completed in the remaining year. It may be possible to meet the target for total retrofitted area, but even if this is the case, the energy savings target will be missed by a considerable margin. The total estimated primary energy saving in 2008 is only 0.27 Mtce, accounting for merely $14 \%$ of the overall target. We attribute the low savings to

\footnotetext{
${ }^{7}$ China Heat Supply Information Net, August 2009. http:// www.reliangbiao.com/jszx/show.asp?id=1420
} 
(1) the incomplete installation of energy efficiency measures in the houses that have been retrofit and (2) the choice of occupants to take the benefits of energy efficiency in improved indoor temperature rather than energy savings. ${ }^{8}$

For the heating supply measurement reform project, only 21 million $\mathrm{m}^{2}$ of building area have completed the heat metering reform, accounting for less than $1 \%$ of the targeted floor area (see Table 4 ). The poor performance in heating supply reform can be partially explained by the fact that thus far only five provinces (Beijing, Tianjin, Shanxi, Gansu, and Jilin) have released policies on heat metering prices and charges. A second problem is that the governmental authority over the heating supply companies is separated from the authority over energy retrofits of buildings, and the incentive thus far provided applies only to the building retrofit.

Another key barrier to the implementation of the program is the lack of a reasonable and feasible financing channel for the owner as well as an economic model for heating supply companies. These companies, which are key players in this activity, generally lack enthusiasm since the retrofit will increase their costs without necessarily increasing income. The method of reimbursing companies for the cost of heat does not take into account the cost of the investment of the end use equipment necessary for the heat metering retrofit. The profit margin has already become low due to the recent increase in coal prices, and together with the relatively long payback period for such projects, it is difficult for companies to make the retrofit investments. Although some successful cases exist such as the residential district of Bao Steel in Inner Mongolia, where the central and local government budget and the enterprise paid the majority of the cost as well as some energy service companies projects in Chengde, Hebei, and Lanzhou, Gansu province, a systematic, widely applicable and mature financing scheme is lacking (Nengyuan net 2009). In any case, the progress made in the heat supply system reform has not been promising, leaving the achievement of the target largely in question in this particular area.

\footnotetext{
${ }^{8}$ A large percentage of the households that were retrofit only installed a heat meter rather than carrying out the full range of retrofit measures, in part because the incentive provided $\left(50 \mathrm{RMB} / \mathrm{m}^{2}\right.$ ) was not sufficient to induce the decision to purchase other, more expensive measures.
}

Qualitative evaluation

Policies set up to target existing buildings include Heat Supply System Measurement and Energy Conservation Retrofits for Existing Residential Buildings in Northern Heating Areas and Energy Management in Government Office Buildings and Large-Scale Public Buildings.

Heat supply system measurement and energy conservation retrofit for existing residential buildings in northern heating areas Energy conservation efforts in the northern heating areas are closely related to heating system reform. This reform was first discussed in 2003, with the main purpose of creating a market-based mechanism to replace heating welfare. One of the core tasks is to replace billing by heated area by actual or estimated use of heat.

As a part of the urban heating system reform, MOC (now MOHURD) also released Interim Management Measures of Urban Heating Price in 2007. The policy provides for heating prices constructed from a fixed price (dependent on floor area) and a price based on heat usage. The fixed price can be in the range of $30-60 \%$ of the total heat price. The guidance also stipulates that new buildings should install heat-measuring devices, while existing buildings should also be equipped with heat measuring devices if affordable.

In late 2007, MOF released an incentive policy for heating system measurement and energy efficiency retrofits. The policy was designed by MOC (now MOHURD), granting incentives to provincial governments. The provincial governments then allocate the fund on a project basis. Retrofit projects supported by the policy include three tasks: building insulation, indoor heating system meter and temperature control device installation, and heat source and network pipeline retrofit. The incentive is $55 \mathrm{RMB} / \mathrm{m}^{2}$ for retrofit in the severe cold zone and $45 \mathrm{RMB} / \mathrm{m}^{2}$ for energy retrofit in the cold zone. ${ }^{9}$ The calculation also includes coefficients for different project types and project progress. The funding is divided for the three tasks indicated above in proportion of 1:3:6 to give different funding allocation to projects with higher

\footnotetext{
${ }^{9}$ The average cost for existing building energy-efficiency retrofits in northern China is estimated to be $150-350 \mathrm{RMB} / \mathrm{m} 2$ (Wu 2009 and http://www.jzcad.com/bbs/archiver/tid-52789.html)
} 
Table 4 Proposed target and estimated achievement to date for existing building retrofits

\begin{tabular}{|c|c|c|c|}
\hline & & $2008^{\mathrm{c}}$ & Target 2010 \\
\hline \multirow[t]{2}{*}{ Existing building ${ }^{\mathrm{a}}$ retrofit } & Retrofit floor area (million $\mathrm{m}^{2}$ ) & 39.5 & 150 \\
\hline & Estimated savings in kgce per $\mathrm{m}^{2}$ & 6.75 & 12.5 \\
\hline \multirow[t]{2}{*}{ Heat supply reform } & Heat supply reform floor area (million $\mathrm{m}^{2}$ ) & 21 & $2,660^{\mathrm{d}}$ \\
\hline & Estimated Savings in kgce per $\mathrm{m}^{2}$ & N.A. & 5 \\
\hline \multicolumn{4}{|c|}{ Primary energy savings (Mtce) } \\
\hline Existing building retrofit & Energy saving (Mtce) & 0.27 & 1.9 \\
\hline Heat system reform & Energy saving (Mtce) & $<0.1$ & 13.3 \\
\hline Total & Primary energy savings (Mtce) & $<0.4$ & 15.2 \\
\hline
\end{tabular}

${ }^{\mathrm{a}}$ This does not include the heat supply reform projects which require heat pricing reform

${ }^{\mathrm{b}}$ This is derived number based on above mentioned methodology, and does not exactly match the announced target. There are no official data on how the target is calculated and assumptions made

${ }^{\mathrm{c}}$ The program had not started by 2008; we thus present the numbers only for 2008

${ }^{\mathrm{d}}$ NBS 2008 (based on the total area of centralized heating in 2006, pp367 of NBS (2008))

energy-saving potential and to encourage retrofit projects to be conducted earlier. Approximately $10 \%$ of the incentive $\left(6 \mathrm{RMB} / \mathrm{m}^{2}\right)^{10}$ was initially given to the provincial government, with settlement of the remaining amount conducted in the end of the year after measuring actual energy-saving effect. The total allocated funding from the central government until the end of 2008 reached 1.54 billion Yuan (Wu 2009). Other than the incentive from the central government, provincial governments are also required to release provincial level incentive policies (Wu 2009).

\section{Energy management of government office buildings and large-scale public buildings}

Quantitative evaluation

Baseline for evaluation of energy management of government office buildings and large-scale public buildings In 2005, the reported building floor area in China was approximately 42 billion $\mathrm{m}^{2}$, and public (commercial) buildings floor area was 4.5 billion $\mathrm{m}^{2}$, accounting for $10.7 \%$ of the total. Of this, 0.33 billion $\mathrm{m}^{2}$ are large-scale public buildings (TUBERC 2009) and together with government office buildings, the total building floor area covered in this program is 0.8 billion $\mathrm{m}^{2}$ (Jin et al. 2009). The

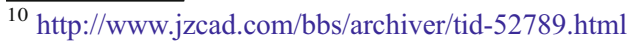

average size of a large commercial building is $33,000 \mathrm{~m}^{2}$ (TUBEERC, 2009), ${ }^{11}$ and the average energy intensity excluding space heating of these buildings is $142.4 \mathrm{kWh} / \mathrm{m}^{2} /$ year. The average energy intensity of the government office buildings excluding space heating is estimated to be $82 \mathrm{kWh} / \mathrm{m}^{2}$.

Calculated savings from energy management of government office buildings and large-scale public buildings The target is to reduce the energy intensity of these buildings by $20 \%$ by $2010,{ }^{12}$ equivalent to savings of 11 Mtce. ${ }^{13}$ Although the government plan has a specific target for energy savings from each program, there are no official data or publications that report the savings to date. In addition, little information has been made public either on the calculation methodology or on the definition of the baseline, thus making it difficult to estimate the actual savings to date. Through extensive literature search and interviews with experts, we assembled information to provide a plausible estimate of energy savings. This is based on estimates of floor area and average energy intensities of the government buildings and large-

\footnotetext{
${ }^{11}$ Derived from the total number of large scale public buildings of 10,000 .

${ }^{12}$ MOHURD has estimated savings based on experience that approximately $10-15 \%$ of the savings could be achieved through energy management (Wu 2009). The saving is estimated to be cumulative over the 5 years.

${ }^{13} \mathrm{http}$ ://www2.tyqgzx.gov.cn:8888/qgbwww/zcfg/gjxzcfg/ 2009-06-24/143.html
} 
scale public buildings. The assumptions and results of this estimate are presented in Table 5 and Fig. 3.

The total floor area of these buildings is estimated to be 0.8 billion $\mathrm{m}^{2}$, and the derived energy consumption (excluding space heating energy) was approximately $84 \mathrm{TWh}$ in 2005. In 2010, the floor area will increase to 0.89 billion $\mathrm{m}^{2}$, and the energy consumption will have dropped to $75 \mathrm{TWh}$ even with new floor area, assuming a decrease in energy intensity of $20 \%$. The derived cumulative energy savings from 2005 to 2010 is $11 \mathrm{Mtce}$, which is consistent with the target stated in MOHURD's Notice of Strengthening the Implementation of Energy Management in Government Office Buildings and Large-Scale Public Buildings. There are no published results on savings to date (2005-2008); however, if the program goal has been achieved, the savings is estimated to be 4.56 Mtce.

Qualitative evaluation

China's government office buildings and other largescale public buildings use more energy per square

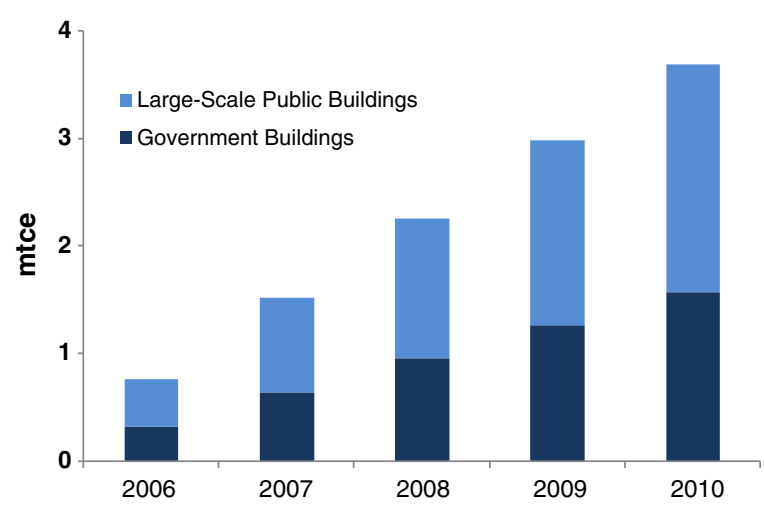

Fig. 3 Estimated program savings due to energy management in government buildings and large-scale public buildings

meter than other forms of buildings. In China, energy conservation efforts in this area concentrate mostly on establishing a supervision and management system and on implementing energy efficiency retrofit measures. This supervision and management system consists of recording energy consumption statistics, performing energy audits, and certifying the energy efficiency of the building.

Table 5 Primary energy savings of the energy management program in government buildings and large-scale public buildings

\begin{tabular}{llll}
\hline & Public buildings & Government buildings & Large-scale public buildings \\
\hline Total floor area (billion $\mathrm{m}^{2}$ ) & & & 0.33 \\
2005 & 4.5 & 0.46 & 0.36 \\
2008 & $5.1^{\mathrm{b}}$ & $0.50^{\mathrm{a}}$ & 0.37 \\
2010 & & 0.52 & 142.4 \\
Energy intensity (kWh/m ${ }^{2}$ year) ${ }^{\mathrm{c}}$ & $30-60$ & $81^{\mathrm{d}}$ & $114^{\mathrm{e}}$ \\
2005 & & 70 & 46.99 \\
2008 & & 64.8 & 42.18 \\
2010 & & & \\
Total estimated energy consumption (TWh) & $135-270$ & 37.26 & 33.696 \\
2005 & & 4.56 & 11.23 \\
2010 & & & \\
Total estimated cumulative savings $05-08$ (Mtce) & & & \\
Total savings target $05-10$ (Mtce) & & & \\
\hline
\end{tabular}

Source: TUBERC 2009; Jin et al. 2009; Zhou et al. 2007

${ }^{a}$ Applying the growth rate of the public building floor area estimated in Zhou et al. (2007)

${ }^{\mathrm{b}}$ Based on LBNL estimate (Zhou et al. 2007)

${ }^{\mathrm{c}}$ Excluding heating

${ }^{\mathrm{d}}$ Based on personal communication

e The target is to reduce energy intensity by $20 \%$ by 2010 , equivalent to $11-15 \mathrm{Mtce}$ http://www2.tyqgzx.gov.cn:8888/qgbwww/zcfg/ gjxzcfg/2009-06-24/143.html. MOHURD estimated savings based on experience that 10-15\% of the savings could be achieved through energy management (Wu 2009) 
To further enhance the energy statistics work in this field, MOHURD has conducted an energy consumption survey of 11,607 government office and large-scale public buildings. MOHURD also carried out an energy audit of 768 buildings and 59 universities, releasing the energy consumption status of these 827 buildings to the public. In addition, a pilot project in 324 buildings in Beijing, Shanghai, Tianjin, and Shenzhen has also been carried out. In these pilot buildings, energy metering devices in each building energy consumption element (e.g. lighting system, elevators, heating, etc.) were installed and connected in real-time to a database. By implementing this measure, comprehensive energy consumption statistics with detailed breakdowns have been gathered.

Apart from above measures, MOHURD is planning an energy consumption quota system for government office buildings and large-scale public buildings ( Wu 2009). This energy consumption quota system is expected to play a large part in stimulating a $5 \%$ decrease in total energy usage in the building sector. This plan will be released in the next 2 years. To support this work, MOF has provided about 100 million RMB for 24 cities (Cai et al. 2009).

With energy consumption statistics and energy audits in buildings as a basis, MOF will also provide a subsidy as a financial support to energy efficiency retrofit projects under the framework of the energy management contracts. Provincial or city level projects will receive $50 \%$ loan interest subsidy, while projects in the central level will get $100 \%$ loan interest subsidy.
Findings

Overall, analysis in this report indicates implementation of the energy standards for new buildings in large urban areas is on track to meet the target. Surveys suggest that in large urban areas the compliance is almost $100 \%$ for the design phase and more than $80 \%$ during enforcement. However, the survey data on which compliance is assessed are not documented nor is there indication of their statistical accuracy. The codes are not in rural areas or in small cities. If enforcement is extended to these areas and is documented, cumulative primary energy savings from new building standards could reach or exceed the 90 Mtce target by 2010 (see Fig. 4).

The challenge in retrofits of existing buildings is not unique to China. There has been little progress in most developed countries. The policy to encourage energy retrofits in existing buildings is far behind target, with limited and inadequate implementation to date. An effective program is especially needed in the cold or very cold weather zones where heating is supplied at low efficiency, control systems in are lacking in most buildings and the buildings built before 2000 are generally of poor thermal quality. The heat supply pricing reform, essential for success of energy-savings programs, is behind schedule and is hampered by the lack of a suitable mechanism and clear responsibility for carrying out the reform in many provinces

There is widespread use of highly energy-intensive building materials, and little consideration for lifecycle energy use. New standards for building materials are needed; authority for building materials and energy efficiency standards are in separate agencies,
Fig. 4 LBNL estimated 2005-2008 building sector primary energy-saving from the programs and policies implemented in $11 \mathrm{FYP}$ (Mtce)
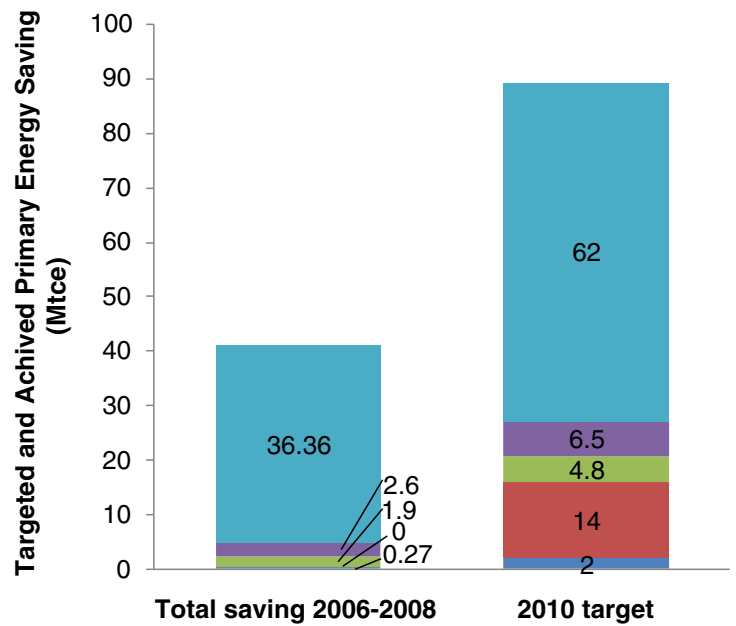

Enforcing Building Codes in New Buildings

- Large-Scale Public Buildings

Government Buildings

- Heat Supply Reform (Mtce)

Exsiting Building Retrofit (Mtce) 
rendering the development and subsequent enforcement of standards for building materials problematic.

For government office buildings and large-scale public buildings, energy management improvements are estimated to have saved 4.6 Mtce between 2005 and 2008 , and should reach a cumulative primary energy savings of 11.2 Mtce by 2010, in line with the target.

Institutionally, China has benefited from a centralized MOHURD and a network of municipal Construction Commissions. MOHURD has worked with the Ministry of Finance to offer incentive mechanisms for building shell measures, but has not adequately addressed major barriers such as changes in urban heating prices and it has no authority over the choice of building materials. More financial mechanisms are needed. Developers lack incentives to include energy-efficient design and materials, and heating supply companies lack incentives to improve the efficiency or install controls on their systems. The lack of official reports and absence of standardized data gathering and baseline definition methodologies make it difficult to determine building energy use and savings. Other data limitations, such as infrequent surveys on building characteristics and energy consumption patterns, further hamper efforts to monitor progress toward 11th FYP goals. Finally, the allocation of building sector energy targets appears not to result from scientific study and has therefore likely led to a mismatch of energy-saving potential and actual energy saving achievements in the building sector.

Nonetheless, the progress China has made in the establishment of the building energy efficiency policy systems are notable: a comprehensive enforcement scheme for new buildings has been established and strictly followed in the large cities where much of the construction takes place; a legal framework for energy efficiency policy is well-established and utilized; the central government has provided incentives and encouraged provinces and cities to provide incentives of their own; and the government officials has worked to update building energy standards.

\section{Recommendations}

Rethink the approach to existing building energy retrofits in cold climates, treating building envelope, control systems, and heat supply together. Because heating represents a significant portion of energy use in existing buildings, more attention should be paid to building retrofit projects and heat supply reform. The existing program consisting primarily of incentives for retrofits is deficient because it fails to address institutional reform (specifically the problems due to the division of responsibility between the heat supply companies and buildings bureaus needed to bring together improvements in heat supply with energy efficiency measures); because the pace of energy pricing reform is too slow; and because there is not adequate scientific consideration of the best and most cost-effective measures to achieve more efficient heating supply, building energy retrofits, and building energy control systems simultaneously. Such an integrated program needs to be established quickly to serve as the basis for implementation during the 12th Five-Year Plan period. Pilot efforts need to be carried out so that the full policy program can be implemented more quickly.

Expand the enforcement of building energy standards that have been effective in large urban areas to the rest of the nation, improve building energy labels and provide incentives for "green building." Continued attention to enforcement of new building energy efficiency standards and the measurement of actual energy use are needed to ensure that efficient designs lead to real energy savings in operation. Energy efficiency policies need to be implemented in medium-small and small cities and in rural areas. ${ }^{14}$ Further incentives are needed to encourage "green buildings" with advanced energy efficiency features. The criteria for green buildings need to place significant emphasis on energy efficiency features of these buildings. In addition, there is a need to develop better characterization of building energy through life cycle analysis, to identify and limit the use of energy-intensive building materials.

Continue to place large emphasis on energy management of large-scale public and governmental buildings. Large-scale public buildings use 10-20 times more than residential buildings. ${ }^{15} \mathrm{~A}$ more robust system should be setup. Such a system would include performing in-depth energy audits of existing buildings, gathering data on building energy performance (preferably before and after retrofit for existing buildings), monitoring the effects of occupant choice in the operation of buildings (temperature set points;

\footnotetext{
${ }^{14}$ Current standards only applies to urban building which encompasses $57 \%$ of the total residential building and $45 \%$ of the total building stock

${ }^{15}$ Per square meter based
} 
schedules of HAVC systems; window openings; and so forth), public reporting on the energy use of buildings; expansion of the use of building energy labels; and extension of the program to medium-sized buildings in large and medium-sized cities.

Enhance policy design and effectiveness through expanded surveys, monitoring, and establishing meaningful baselines of building energy consumption/efficiency. Standardization of data gathering methodologies and greater public availability of data are needed to inform 12th FYP policy design and monitoring. Building energy consumption data and data reporting methodologies should be made more transparent for better evaluation of policy progress, including analysis by outside independent organizations. Surveys on building characteristics and energy consumption patterns that are representative of national building stock should be conducted on a regular basis. A scientific baseline needs to be developed to reflect the energy efficiency improvement in buildings and the increasing demand for more comfort and delivered energy services. In addition, benchmarking protocols should be developed to monitor building energy consumption and allow better comparison among buildings.

Open Access This article is distributed under the terms of the Creative Commons Attribution Noncommercial License which permits any noncommercial use, distribution, and reproduction in any medium, provided the original author(s) and source are credited.

\section{References}

Cai, W. G., Wu, Y., Zhong, Y., \& Ren, H. (2009). China building energy consumption: situation, challenges and corresponding measures. Energy Policy, 37(6), 2054-2059.

Feng Fei, Wang Jinzhao, Li Minzhi, Wang Qingyi, Wang Xuejun, and He Kebin. 2009. Midterm evaluation of implementation of the work of Energy Conservation and Emission Reduction during the Eleventh Five-Year Plan and Policy Directions under new situation.
Hao Bin 2009. "Building Energy Efficiency Evaluation and Labeling (BEEEL)". (2009). Presentation and discussion at the informal session of the European Council for an Energy Efficient Economy Summer Study proceedings, June 5, 2009. France: Nice.

Jing, Z., \& Yong, Wu. (2009). Introduction: theory and practice on building energy efficiency in China. Energy Policy, 37 (6), 2053.

Ministry of Construction (MOC)/Ministry of Housing and Urban-Rural Development (MOHURD). 2008. The Notice on Implementation of the Civil Building Energy Conservation Ordinance. Available from: http://www.cin.gov.cn/ ZCFG/jswj/jskj/200812/t20081211_183179.htm. Accessed 20 Sep 2009.

National Bureau of Statistics (NBS). (2008). China statistical yearbook. Beijing: NBS.

National Development and Reform Commission (NDRC). 2006. Implementation suggestions of ten key energy-conservation projects during the Eleventh Five-Year Plan, NDRC Department of Resource Conservation and Environmental Protection Document \#: [2006]1457.

Nengyuan net. 2009. Why is the building energy efficiency retrofit difficult? Nengyuan net. Available from: http:// www.nengyuan.net/200908/03-200105.html. Accessed 5 Aug 2009.

Qiu Baoxing. 2009. "From special inspection to fiscal subsidyannual perspective of architectural energy-saving in China." Available from: http:/www.chinagb.net/news/fugle/ 20090330/46797.shtml. Accessed 5 Aug 2009.

Tsinghua University Building Energy Efficiency Research Centre (TUBERC). (2009). 2009 Annual report on China building energy efficiency. Beijing: China Building industry Publishing Company.

Wu Yong. 2009. Personal communication with $\mathrm{Wu}$ Yong. MOHURD, May 8, 2009.

Xinhua. 2007. "Half of the new global construction built in China," Available from: http://news.xinhuanet.com/ newscenter/2007-08/23/content_6593780.htm. Accessed 6 Aug 2009.

Zhenxing, Jin, Yong, Wu, Baizhan, Li, \& Yafeng, Gao. (2009). Energy efficiency supervision strategy selection of Chinese large-scale public buildings. Energy Policy, 37(6), 20662072.

Zhou, N., \& Lin, J. (2008). The reality and future scenarios of commercial building energy consumption in China. Energy\& Buildings, 40(12), 2121-2127.

Zhou, N., McNeil, M., Fridley, D., Lin, J., Price, L., du Can, Rue, et al. (2007). Energy use in China: sectoral trends and future outlook. LBNL-61904. Berkeley, CA: Lawrence Berkeley National Laboratory. 